1 Expression of genes involved in key metabolic processes during winter flounder

2 (Pseudopleuronectes americanus) metamorphosis

3

4 Marie Vagner, Benjamin de Montgolfier, Jean-Marie Sévigny, Réjean Tremblay, and

5 Céline Audet

6

7 Marie Vagner, Benjamin de Montgolfier, Réjean Tremblay, and Céline Audet: Institut

8 des Sciences de la Mer (ISMER), Université du Québec à Rimouski (UQAR), 310 allée des

9 Ursulines, Rimouski (QC), Canada G5L 3A1

Jean-Marie Sévigny: Institut Maurice-Lamontagne, Pêches et Océans Canada, 850 route de

11 la mer, Mont-Joli (QC), Canada G5H 3Z4

12

13 E-mail addresses: marie.vagner@univ-lr.fr (M. Vagner), benou2m@yahoo.fr (B. de

14 Montgolfier), jean-marie.sevigny@dfo-mpo.gc.ca (J.M. Sévigny),

15 rejean_tremblay@uqar.qc.ca (R. Tremblay), celine_audet@uqar.qc.ca (C. Audet)

16

17 Corresponding author: Marie Vagner, LIENSs UMR 7266 (CNRS - Université de La

18 Rochelle), 2 rue Olympe de Gouges, 17000 La Rochelle, France; Tel : +33 5465076 39;

19 Fax : +33 5465076 63; marie.vagner@univ-lr.fr

20

21

Marie Vagner : Present address: LIENSs UMR 7266 (CNRS - Université de La Rochelle), 2 rue Olympe de Gouges, 17000 La Rochelle, France; Tel : +33 5465076 39; Fax : +33 546 507663.

Benjamin de Montgolfier : Present address: 23 place de la mairie, 34160 Saussines, France; Tel : +33696844120. 


\section{Expression of genes involved in key metabolic processes during winter flounder}

\section{3 (Pseudopleuronectes americanus) metamorphosis}

25 M. Vagner, B. de Montgolfier, J.-M. Sévigny, R. Tremblay, and C. Audet

\section{Abstract}

28 The aim of this study was to better understand the molecular events governing ontogeny

29 in winter flounder Pseudopleuronectes americanus. The expression of seven genes

30 involved in key metabolic processes during metamorphosis were measured at settlement

31 (S0), at 15 (S15), and 30 (S30) days after settlement and compared to those in pelagic

32 larvae prior to settlement (PL). Two critical stages were identified: 1) larval transit from

33 the pelagic to the benthic habitat (from PL to S0) and 2) metamorphosis maturation,

34 when the larvae stay settled without growth (from S0 to S30). Growth hormone (gh) gene

35 expression significantly increased at S0. At S30, an increase in cytochrome oxidase (cox)

36 gene expression occurred with a second surge of $g h$ gene expression, suggesting that

37 enhanced aerobic capacity was supporting growth before the temperature decrease in the

38 fall. Expression patterns of pyruvate kinase, glucose-6 phosphate dehydrogenase, and

39 bile salt-activated lipase genes indicated that energy synthesis may be mainly supplied

40 through glycolysis in PL, through the pentose-phosphate pathway at settlement, and

41 through lipid metabolism at S30. The expression of the heat-shock protein 70, superoxide

42 dismutase, cox, and peroxiredoxin-6 genes revealed that oxidative stress and the

43 consequent development of antioxidative protection were limited during the PL stage, 
44 reinforced at settlement, and very high at S30, certainly due to the higher growth rate

45 observed at this period.

46

47 Keywords: metamorphosis; growth hormone; antioxidant enzymes; energy metabolism;

48 winter flounder, Pseudopleuronectes americanus.

49 


\section{Introduction}

51 Metamorphosis can be defined in many ways. In the context of the present study,

52 it refers to the "transitions from a larva to a juvenile, including morphological,

53 physiological, and behavioural modifications that proceed while a larva transforms to a

54 juvenile" (Bishop et al. 2006). At least four components of metamorphosis are shared

55 among species: (1) the differentiation of juvenile/adult structures, (2) the degeneration of

56 larval structures, (3) the metamorphic competence, and (4) the change in habitat (Heyland

57 and Moroz 2006). During this period, animals undergo profound physiological and

58 morphological modifications that are controlled by a coordinated change in gene

59 expression (Baolong et al. 2005; Hildahl et al. 2007; Wang et al. 2011). In flatfish,

60 metamorphosis is characterized by a striking anatomical transformation involving a $90^{\circ}$

61 rotation in body position, the development of asymmetrical pigmentation, and the

62 migration of one eye towards the other on the upper side of the fish (Fuiman 1997). This

63 process occurs concomitantly with the transition from the pelagic to the benthic habitat

64 (Fuiman 1997; Gibson 1997; Geffen et al. 2007), bringing modifications in feeding

65 behaviour, type of prey, and digestive physiology (Tanaka et al. 1996; Lagardère et al.

66 1999; Cañavate et al. 2006).

67 All these biological and behavioural changes occurring during fish metamorphosis

68 induce a particularly high metabolic demand (Geffen et al. 2007). To meet this demand,

69 fish at early life stages must rapidly develop their metabolic pathways to obtain energy

70 from protein, lipid, and carbohydrate metabolism (Slenzka et al. 1995; Geffen et al.

71 2007). Several studies reported that the activities of enzymes involved in energy and lipid

72 metabolism may change during metamorphosis depending on fish needs during this 
73 period and on the species considered (Segner and Verreth 1995; Slenzka et al. 1995;

74 Bishop and Torres 1999; Ribeiro et al. 1999; Hoehne-Reitan 2001; Murray et al. 2003).

75 To meet the high metabolic demand related to the development of all metabolic

76 pathways occurring during metamorphosis, fish must increase exogenous oxygen

77 consumption. This can increase the production of reactive oxygen species (ROS), which

78 are waste products from mitochondrial oxidation and may cause damage to lipids,

79 proteins, and DNA in fish tissues (Fridovich 2004). ROS are continually detoxified and

80 removed from cells by antioxidant enzymes such as peroxiredoxins (Prx), superoxide

81 dismutase (Sod), and cytoprotection enzymes like heat-shock proteins (Hsp). The activity

82 of antioxidant enzymes during fish metamorphosis has been widely studied in several

83 larval fish species, including common dentex Dentex dentex (Mourente 1999), trout

84 Salmo iridaeus (Aceto et al. 1994), and sprat Sprattus sprattus (Peters et al. 2001) as well

85 as in flatfish species, such as turbot Scophthalmus maximus (Peters and Livingstone

86 1996).

87 Several authors have studied fish metamorphosis through variations in the

88 activities of enzymes involved in key metabolic pathways, but information regarding the

89 genetic processes underlying these changes is more limited. In a review comparing

90 metamorphosis processes in different animal groups, Heyland and Moroz (2006) showed

91 that, despite significant differences of transcription levels detected by microarray or other

92 molecular methods, some similarities can be observed among taxa. Transcripts related to

93 stress response, immunity, and apoptosis are associated with metamorphosis in all

94 investigated phyla, and regulation signals mediated by hormones and by nitric oxide can

95 act as regulators of metamorphic transitions. 
96 In addition to the traditional morphological, biochemical, physiological, and

97 histological markers, molecular markers could be used to generate useful insight on

98 individual physiological performance during metamorphosis. In this context, the aim of

99 this study was to better understand the molecular events governing ontogeny in flatfishes

100 by measuring the expression of genes involved in key metabolic processes (growth, lipid

101 metabolism, energy metabolism, oxidative stress, and cytoprotection) during flatfish

102 metamorphosis using quantitative PCR (qPCR). By comparing the gene expressions of

103 pelagic larvae with those of settled larvae through the metamorphosis process, we tested

104 the hypothesis that genes coding for hormones or enzymes involved in growth, lipid

105 metabolism, energy metabolism, oxidative stress, and cytoprotection are differentially

106 expressed during the transition from pelagic to benthic life.

107 The expressions of the gene coding for growth hormone $(g h)$, two genes for

108 antioxidant enzymes (prx6, sod), one for cytoprotection (hsp 70), three for enzymes

109 involved in energy metabolism (cytochrome oxidase cox, pyruvate kinase $p k$, and

110 glucose-6 phosphate dehydrogenase g6pd), and one for an enzyme involved in lipid

111 metabolism (bile salt-activated lipase bal) were measured using qPCR analyses during

112 the first weeks following settlement of a common flatfish species of the Northeast

113 Atlantic coast, the winter flounder Pseudopleuronectes americanus.

115 Material and methods

116 Biological material

117 Winter flounder Pseudopleuronectes americanus is a common inshore flatfish that

118 occurs from Labrador (Atlantic Canada, $53^{\circ} \mathrm{N}$ ) to Georgia (southeast United States, 
$11933^{\circ} \mathrm{N}$; Scott and Scott 1988). Most studies regarding metamorphosis in this species have

120 investigated size and age at settlement (Chambers and Leggett 1987; Chambers and

121 Leggett 1992; Fraboulet et al. 2009), temperature effects on growth (Chambers and

122 Leggett 1992; Benoît et al. 2000; Fraboulet et al. 2010; 2011), and requirements in

123 nutrient or abiotic parameters for aquaculture production (Ben Khemis et al. 2000;

124 Seychelles et al. 2009; Fraboulet et al. 2011).

125

\section{Fish rearing conditions}

127 All experiments were conducted at the Station aquicole de Pointe-au-Père (ISMER 128 / UQAR; $48^{\circ} 27^{\prime} \mathrm{N}, 68^{\circ} 32^{\prime} \mathrm{W}$; QC, Canada). Fish manipulations were done according to

129 the Canadian Council of Animal Protection recommendations, and protocols were 130 approved by the University Animal Care Committee.

131 Egg stripping and fertilization were done according to Ben Khemis et al. (2000).

132 Once hatched (day 0), larvae were transferred into nine 55 L cylindro-conical tanks

133 (density: 250 larvae $\left.\mathrm{L}^{-1}\right)$ set in a temperature-controlled room $\left(10^{\circ} \mathrm{C}\right)$, and exposed to a

134 12L:12D photoperiod cycle. Tanks were supplied with flowing filtered ambient sea water

135 except during the feeding period (09:00-17:00), when flow was stopped. A permanent

136 up-welling current was maintained in each tank by the aeration system placed at the

137 bottom of a vertical strainer. From mouth opening at four days post-hatching (dph) until

138 the end of the experiment, larvae were fed rotifers Brachionus plicatilis $\left(5 \mathrm{ind} . \mathrm{ml}^{-1}\right)$

139 enriched with a mixture of three microalgae that fulfilled the fishes' energy requirement:

140 Nannochloropsis oculata, Isochrysis galbana, and Pavlova lutheri (see Seychelles et al.

1412009 for the enrichment protocol). 
When settlement occurred ( $45 \mathrm{dph})$, newly settled larvae were collected every

143 three days and transferred into rectangular tanks $(35.5 \times 65 \times 6.5 \mathrm{~cm})$. Each replicate tank

144 contained 300 individuals. Settled larvae were reared according to Fraboulet et al. (2010),

145 using flowing filtered seawater $\left(50 \mu \mathrm{m}, 2 \mathrm{~L} \mathrm{~min}^{-1}\right)$ and under natural conditions of

146 temperature $\left(10.4 \pm 1^{\circ} \mathrm{C}\right)$, salinity $(28.8 \pm 1.3)$, and photoperiod (artificial light 400 lux,

147 12L:12D). Each day, settled larvae were fed the same diet as during the larval stage (5

148 rotifers $\mathrm{ml}^{-1}$ at 11:00, 13:00, and 16:00), completed with 10 microdiet meals (Gemma

149 wean; www.skretting.com) in excess every 30 min between 09:00 and 11:00 and between

$150 \quad 13: 30$ and 15:30. Seawater flow was stopped from 09:00-12:00 and 13:00-17:00 to avoid

151 rotifer loss. Water was renewed between 12:00 and 13:00 and overnight. Dead

152 individuals and excess feed were removed every day and tanks were cleaned every two

153 weeks.

154

\section{Samplings}

156 Samplings were done early in the morning before the first meal to allow a $12 \mathrm{~h}$

157 fast prior to sampling. Pelagic larvae (PL) and newly settled larvae (S0) were sampled

158 both on the same day, i.e., at the peak of settlement. Fish were also sampled 15 and 30

159 days after settlement (S15 and S30). At each sampling period, 10 individuals per tank

160 were collected and anaesthetized (MS 222, 0.05g L $\left.\mathrm{g}^{-1}\right)$ for growth measurements and four

161 subsamples of five or six larvae were fixed in five volumes of RNAlater ${ }^{\circledR}$ (Applied

162 Biosystems, CA, USA) for $24 \mathrm{~h}$ before being frozen at $-80^{\circ} \mathrm{C}$ for further gene expression

163 measurements.

164 


\section{Growth measurements}

166 Total body length, standard length (i.e., notochord length), and maximum body

167 width were measured using a micrometer $( \pm 0.1 \mathrm{~mm})$.

\section{Gene expression measurements}

170 Total RNA was extracted from $30 \mathrm{mg}$ of fish using the RNeasy Plus Mini Kit ${ }^{\circledR}$

171 (Qiagen, Inc., ON, Canada) according to the manufacturer's instructions. Total RNA

172 purity and concentration were controlled using the $260 / 280 \mathrm{~nm}$ absorbance ratio

173 measured with a NanoDrop ${ }^{\circledR}$ instrument (NanoDrop ND-1000 spectrophotometer v3.3.0,

174 NanoDrop Technologies, Inc., DE, USA). RNA purity was also assessed by ethidium

175 bromide staining of $28 \mathrm{~S}$ and $18 \mathrm{~S}$ ribosomal RNA bands separated by electrophoresis on a

$176 \quad 1.2 \%$ agarose gel. cDNAs were immediately obtained by reverse transcription (in

177 duplicate) on $1 \mu \mathrm{g}$ of total RNA from each sample using a Quantitect Reverse

178 Transcription $\mathrm{kit}^{\circledR}$ with integrated removal of genomic DNA contamination (Qiagen, Inc.,

179 ON, Canada). cDNA concentrations were estimated using a NanoDrop

180 spectrophotometer. Duplicate cDNAs were pooled for each sample and stored at $-20^{\circ} \mathrm{C}$

181 until analyses. qPCR was performed for each sample on pooled cDNA using the iCycler

$182 \mathrm{iQ}^{\mathrm{TM}}$ (Bio-Rad Laboratories Inc., ON, Canada).

183 The mRNA sequences for the cox (GenBank accession no. EU752157), bal

184 (GenBank accession no. AF512561), g6pd (GenBank accession no. AY225097), and

185 prx6 (GenBank accession no. AY156726) genes were available for Pseudopleuronectes

186 americanus in the GenBank ${ }^{\circledR}$ database (Benson et al. 2005), but those for $p k, h s p 70, g h$,

187 sod, and glyceraldehyde phosphate dehydrogenase gapdh were not. Consequently, 
188 primers were designed from the mRNA sequences of other species to obtain PCR

189 products ranging from 90 to $150 \mathrm{bp}$. Primers for $h s p 70$, gapdh, gh, and $s o d$ were designed

190 from sequences available for Paralichtys olivaceus (GenBank accession no. AB010871,

191 GenBank accession no. AB029337, GenBank accession no. M23439, and GenBank

192 accession no. EF681883.1, respectively) using Primer Express ${ }^{\circledR}$ software v.3.0 (Applied

193 Biosystems, CA, USA). Primers for $p k$ were designed from alignments between mRNA

194 sequences of Scophthalmus maximus (GenBank accession no. AF467775) and Salmo

195 salar (GenBank accession no. NM_001141703) using Primer $3^{\circledR}$ software (Rozen and

196 Skaletsky, 2000). The primer sequences used for each gene are summarized in Table 1.

197 For each gene, the amplicon obtained was sequenced to assess the specificity of forward

198 and reverse primers. Sequencing was performed using ligation with the TOPO TA

199 Cloning Kit for Sequencing ${ }^{\circledR}$ (Invitrogen Inc., ON, Canada), and transformation was done

200 using One Shot Chemically Competent E. coli ${ }^{\circledR}$ (Invitrogen Inc., ON, Canada). Bacterial

201 cDNA was extracted using the EZNA Plasmid Mini Kit $\mathrm{I}^{\circledR}$ (Omega Bio-Tek, GA, USA).

202 Nucleotides were isolated with the Ultra-Step Dye Terminator Removal Kit ${ }^{\circledR}$ (Eazy

203 Nucleic Isolation, EZNA, Omega Bio-Tek, GA, USA) and sequenced in forward and

204 reverse directions using the Big Dye Terminator v3 chemistry ${ }^{\mathbb{B}}$ (Applied Biosystems,

205 CA, USA). For each gene, the sequence obtained was compared to the sequence(s) used

206 for the primer design using BLAST ${ }^{\circledR}$ software (Altschul et al. 1990). Sequence lengths

207 and percentages of similarity with the reference sequences are presented in Table 1.

208 qPCR analyses for each gene were performed in duplicate for each pool of cDNA

209 in a total volume of $15 \mu \mathrm{l}$ containing $5 \mu \mathrm{lDNA}$ (mean initial concentration $20.0 \pm 2.4$

$\left.210 \mu \mathrm{g} \mathrm{ml}^{-1}\right)$ diluted by $10^{-2}, 0.5 \mu \mathrm{l}$ primers $\left(10 \mu \mathrm{mol} \mathrm{l}^{-1}\right), 1.5 \mu \mathrm{l}$ of sterile water, and $7.5 \mu \mathrm{l}$ 
$2112 X$ iQ SYBR Green Supermix ${ }^{\circledR}$ (Bio-Rad laboratories, Inc., ON, Canada). Thermal

212 cycling of real-time PCR consisted of an initial incubation at $95^{\circ} \mathrm{C}$ for $13.5 \mathrm{~min}$ followed

213 by 45 cycles of denaturing at $95^{\circ} \mathrm{C}$ for $30 \mathrm{~s}$, annealing at $60^{\circ} \mathrm{C}$ for $1 \mathrm{~min}$, and elongating

214 at $72^{\circ} \mathrm{C}$ for $30 \mathrm{~s}$. Cycle threshold (CT) values correspond to the number of cycles at

215 which the fluorescence emission monitored in real time exceeded the threshold limit. CT

216 values were automatically calculated on the log curve for each gene. Following PCR

217 amplification, a melting curve was performed for each gene to ensure the accuracy of

218 quantification: 45 cycles for cDNA amplification were followed by one cycle at $95^{\circ} \mathrm{C}$ for

$2191 \mathrm{~min}$, one cycle at $55^{\circ} \mathrm{C}$ for $1 \mathrm{~min}$, and 80 cycles at $55^{\circ} \mathrm{C}$ for $10 \mathrm{~s}$.

220 To determine the relative quantity of target gene-specific transcripts present in

221 each subsample, CT were averaged for each duplicate and then for each tank, and relative

222 expression was calculated according to the equation from Livak and Schmittgen (2001):

223

$$
2^{-\Delta \Delta^{\wedge} \mathrm{CT}}=2^{\wedge-(\Delta \mathrm{CTe}-\Delta \mathrm{CTc})}
$$

224 where $\mathrm{CTe}=\mathrm{CT}$ target gene $-\mathrm{CT}$ reference gene for the sample $\mathrm{x}$ and

$225 \mathrm{CTc}=\mathrm{CT}$ target gene $-\mathrm{CT}$ reference-gene for the calibrator.

226 In our study, the calibrator was the pelagic larval stage (PL group). gapdh was

227 used as a reference gene because its expression remained constant between samples and

228 through developmental stages. Standard curves (done in triplicate) were established for

229 each developmental stage by plotting the CT values against the $\log _{10}$ of five different

230 dilutions (in triplicate) of a pool of representative cDNA sample solutions. The absence

231 of any effect of developmental stage on the reference gene was examined with a test of

232 slope homogeneity $(F=0.00 ; n=4 ; p=0.99>0.05)$ followed by an ANCOVA $(F=$

$2330.11 ; n=4 ; p=0.95>0.05)$ using Statistica $^{\circledR}$ (Statsoft v.6.1, Tulsa, OK, USA). 


\section{Statistical analyses}

$236 \quad$ All statistical tests were performed with Statistica ${ }^{\circledR}$. Normality and

237 homoscedasticity of data were tested using Kolmogorov-Smirnov's test and Levene's

238 test, respectively. Gene expression data were transformed using $\log (x+1)$ to obtain

239 homoscedasticity. The effects of developmental stage (PL, S0, S15, and S30) on fish

240 growth (total length, standard length, and maximum width) and gene expression were

241 tested using one-way ANOVA. When a significant effect was found, the unequal Tukey

242 test was applied if ANOVA assumptions were met. For prx6 gene expression,

243 homoscedasticity was not met using classic transformation, so Fisher's LSD was applied

244 on rank-transformed data (Quinn and Keough, 2002). Differences were considered

245 significant at $p<0.05$.

246

247 Results

248

249 Standard body length did not increase with later developmental stage, while total

250 length and maximum width were significantly affected $\left(p<0.001, F_{3}=12.45\right.$ and $p<$

$2510.001, F_{3}=43.61$, respectively; Fig. 1) and varied similarly. Between PL and S0, body

252 width increased significantly by 1.6 fold, remained unchanged between S0 and S15, and

253 increased again at S30 (Fig. 1A). Total length varied from an average of $6.60 \pm 0.08 \mathrm{~mm}$

254 in PL, S0, and S15 to $7.48 \pm 0.17 \mathrm{~mm}$ in S30 (Fig. 1B).

$255 \quad$ The $g h$ gene expression significantly increased with developmental stages (Fig. 2;

$\left.256 p<0.001, F_{3}=44.61\right)$. It significantly increased by about threefold from PL stage to S0, 
257 and it was 14 times higher than in the PL group 30 days after settlement. There was no

258 significant difference between S0 and S15.

259 The g6pd gene expression greatly increased from PL to S0, by up to 13 times

260 (Fig. $3 \mathrm{~A} ; p<0.001, F_{3}=70.72$ ). It then decreased sevenfold from $\mathrm{S} 0$ to $\mathrm{S} 15$ and

261 remained unchanged until S30. The bal gene expression was 2.5 times higher at S30 than

262 in the PL and $\mathrm{S} 0$ groups (Fig. 3B; $p<0.01, F_{3}=5.13$ ). Relative gene expression was

263 intermediate in the S15 group, indicating that the expression activation had begun at this

264 stage. Expression of the $p k$ gene continuously decreased following settlement to reach the

265 lowest relative expression level at $\mathrm{S} 30$ (Fig. $3 \mathrm{C} ; p<0.05, F_{3}=3.12$ ), while $c o x$ gene

266 expression was about twofold higher in the S30 group than in the other groups (Fig. 3D;

$\left.267 p<0.01, F_{3}=5.87\right)$.

268 The prx6 gene expression increased at settlement relative to the PL group and

269 remained relatively unchanged afterward (Fig. $4 \mathrm{~A} ; p<0.05, F_{3}=4.15$ ). The sod gene

270 expression decreased from settlement to $\mathrm{S} 0$ and $\mathrm{S} 15$ and then increased to $\mathrm{S} 30$ (Fig. 4B; $p$

$\left.271<0.01, F_{3}=13.01\right)$. The $h s p 70$ gene expression increased at S15 and S30 and was about

272 sevenfold higher than at settlement and in the PL group (Fig. 4 C; $p<0.001, F_{3}=29.03$ ).

273

274 Discussion

275

276 The aim of this study was to better understand the molecular events governing

277 ontogeny in winter flounder Pseudopleuronectes americanus by measuring the

278 expression of seven genes involved in key metabolic processes. The results provided

279 insight on specific variations of growth, lipid metabolism, energy metabolism, oxidative 
280 stress, and cytoprotection that may occur during the transition from a pelagic to a benthic 281 lifestyle.

\section{Stage development and $g h$ expression}

284 Morphological data clearly indicated different steps in winter flounder growth. A

285 settled larva was significantly wider than a pelagic larva and its length and width did not

286 change until 30 days post settlement, when individual growth in width and length

287 increased again. Based on these observations, we identified two main critical stages

288 related to winter flounder metamorphosis: 1) larval transit from the pelagic to the benthic

289 habitat and 2) the metamorphosis maturation, when the larvae stay settled without

290 growth.

291 Morphological modifications in length and width during winter flounder

292 metamorphosis are reinforced by $g h$ gene expression data, with $g h$ expression increasing

293 at the same time as the body length and/or width increases. Thus, $g h$ could be a useful

294 indicator of the two main critical stages identified during metamorphosis since it first

295 increased during the settlement phase and then again with an even larger increase at the

296 beginning of the juvenile stage (30 days after settlement). These results are in accordance

297 with the hypothesis of Heyland and Moroz (2006) that specific hormones act as a signal

298 regulating development in larvae and as a regulator of the metamorphic transition.

299 Moreover, the role of thyroid hormones (Infante et al. 2008) and insulin-growth factor-1

300 (Hildahl et al. 2008) as well as Gh (Hildahl et al. 2008) and Igf-1 receptors (Escobar et al.

301 2011) in the regulation of metamorphosis has recently been highlighted in different fish 302 species. 
Gh is essential for the hepatic production of the insulin-like growth factors (Igf-1

304 and Igf-2), which mediate the anabolic actions of Gh (for review see Yousefian and

305 Shirzad 2011). We designed primers to study the expression of Igf-1 based on sequences

306 already identified in other fish species. Unfortunately, none allowed the amplification of

307 a homologous sequence.

309 Changes in metabolic strategy

310 The $p k, c o x, g 6 p d$, and bal gene expressions could indicate changes in metabolic

311 strategy during metamorphosis. These changes could be linked with changes in activities

312 related to energy metabolism, in feeding behaviour, and in digestive physiology observed

313 in flatfish during metamorphosis in natural environments (Tanaka et al. 1996; Lagardère

314 et al. 1999; Cañavate et al. 2006). Strong morphological and functional changes in the

315 digestive system have been observed during metamorphosis in Japanese flounder

316 Paralychtis olivaceus (Tanaka et al. 1996). The authors suggested that these changes

317 were related to a shift in the diet at settlement from zooplanktonic to benthic prey.

318 From the pelagic larval to the beginning of the juvenile stage (S30), $p k$ gene

319 expression significantly decreased, suggesting that the glycolysis pathway is more a

320 larval pathway than a juvenile one. Pk is an enzyme involved in the last step of

321 glycolysis, allowing the phosphorylation of adenosine di-phosphate (ADP) to adenosine

322 tri-phosphate (ATP). The higher expression of the $p k$ gene in PL than in S30 may indicate

323 a higher anaerobic capacity of larvae compared to juveniles. In pelagic fish, an increase

324 in the anaerobic potential has been associated with the necessity for short-term

325 anaerobically powered swimming bursts during feeding and predator-prey interactions 
326 that require rapid and efficient production of ATP (Childress and Somero 1990). This

327 could apply to pelagic marine fish larvae that may be more exposed to predators than

328 juveniles, which can hide in the bottom substrate. Moreover, the decrease in gene

329 expression related to the glycolysis pathway in settled juveniles compared to pelagic

330 larvae combined with the increase in cox gene expression measured at S30 suggest a

331 higher aerobic capacity in juveniles. This may reflect an increased aerobic metabolic rate

332 due to tissue reorganization and higher growth rate ( $g h$ gene expression, total length, and

333 maximum width) occurring at the same time. In contrast, Darias et al. (2008) used

334 microarrays to show an increased expression of genes involved in

335 neoglucogenesis/glycolysis in larval European seabass, with a significantly higher

336 anaerobic capacity at the end of the larval stage.

337 At settlement, g6pd gene expression strongly increased, suggesting a shift from

338 glycolysis to pentose-phosphate metabolism for this stage. Activation of the pentose-

339 phosphate pathway would be necessary to supply a large quantity of ribose units for

340 nucleotide synthesis and thus support the high demand for newly formed RNA and DNA

341 in fast-growing juveniles. This is in accordance with Munilla-Moran and Stark (1989),

342 who observed no detectable levels of G6pd enzyme activity in turbot Scophthalmus

343 maximus larvae, thereby concluding that the pentose-phosphate pathway is inoperative

344 during early life in turbot. Segner and Verreth (1995) also reported very low levels of

345 G6pd enzyme activity in early life stages of the pelagic catfish Clarias gariepinus that

346 increased through development.

347 At the juvenile stage (from S30), when growth resumes, bal gene expression

348 dramatically increased, suggesting that winter flounder once again changed its strategy to 
349 rely mainly on lipid metabolism to support its growth and development. Using semi-

350 quantitative PCR, Murray et al. (2003) reported an increase in bal gene expression from

351 the larval to juvenile stage in winter flounder. They showed that this enzyme may use

352 different lipid substrates, including triacylgycerols. While analyzing the fate of lipid

353 classes from metamorphosis to 45 days post-settlement ( $45 \mathrm{dps}$ ) by thin-layer

354 chromatography, Fraboulet et al. (2010) showed that even though they represented only a

355 small fraction of the total lipids, triacylglycerols dropped by $79 \%$ during the growth

356 period occurring from settlement to $45 \mathrm{dps}$. These observations confirmed that lipid

357 metabolism becomes the main pathway to support juvenile development, and changes in

358 gene expression that will lead to lipase production take place two weeks after settlement.

359 Since the Bal enzyme is mostly produced by the pancreas in winter flounder (Murray et

360 al. 2003), the increase in bal gene expression observed in the present study at S30 could

361 indicate that the pancreas continues to develop during the juvenile settlement stage (from

362 S30). Moreover, this increase could not be related to the food spectrum and feeding

363 protocol, as suggested in a previous study (Borlongan 1990), because settled larvae were

364 fed the same diet (with the same lipid composition) using the same feeding protocol

365 throughout the experiment. This increase in bal gene expression at S30 suggests that fish

366 development not only corresponds to the very beginning of metamorphosis in winter

367 flounder, but also that it continues until around a month after settlement.

368

369 Antioxidant enzymes

370 The present study reveals the expression of genes coding for antioxidant enzymes

371 (prx6 and sod) and cytoprotection ( $h s p 70)$ from pelagic larval to benthic juvenile stages 
372 in P. americanus. The results obtained demonstrate that all antioxidant genes tested

373 showed a maximal relative expression at S30, suggesting an increased response to stress

374 and antioxidant protection at the juvenile stage. Accordingly, in the sturgeon Acipenser

375 naccarii, an increased activity of antioxidant enzymes (Sod, catalase, glutathione

376 peroxidase, and glutathione reductase) was observed during the juvenile stage (Díaz et al.

377 2010). In winter flounder, the expression of these genes evolved in different ways during

378 metamorphosis.

379 The sod gene expression suggested that this enzyme played a major role during

380 the pelagic larval stage, settlement, and the beginning of the juvenile stage. Previous

381 studies reporting Sod enzyme activity in larval fish showed that the enzymatic activity

382 varies according to the species considered: a decrease in Sod activity throughout larval

383 development was demonstrated in turbot (Peters and Livingstone 1996) and in common

384 dentex (Mourente et al. 1999) while an increase was demonstrated in larval trout Salmo

385 iridaeus (Aceto et al. 1994). Kalaimani et al. (2007) did not report any difference in Sod

386 activity throughout larval development in the Asian seabass Lates calcarifer.

387 Except for sod, the expression of the two other genes coding for antioxidant

388 enzymes or cytoprotection were lowest during pelagic larval stage. This is in accordance

389 with the use of glycolysis metabolism during this period. Glycolysis is an anaerobic

390 process, and as a consequence it limits oxidative stress (Wu and Wei 2011). The use of

391 this type of metabolism could be an adaptation by fish to limit their oxidative stress

392 during the critical larval period.

393 At settlement, detoxification seems to be enhanced by Prx6. The Prx6 enzyme

394 plays a protective antioxidant role in cells, reducing and detoxifying hydrogen peroxide, 
395 peroxinitrite, and a wide range of organic hydroperoxides (Wood et al. 2003). The

396 different gene expression patterns observed for sod and prx6 can be explained by the fact

397 that the two enzymes use different substrates: Sod catalyzes the dismutation of

398 superoxide in oxygen and hydrogen peroxide that must be further detoxified by Prx6.

399 Thus, the large amounts of hydrogen peroxide produced at the PL stage by Sod will be

400 further detoxified by Prx6 starting at settlement. Prxs are the most recently discovered

401 group of antioxidant enzymes, and while they have been cloned and characterized in

402 several fish species (channel catfish Ictalurus punctatus, Yeh and Klesius 2007; Gilthead

403 seabream, Pérez-Sánchez et al. 2011) including flatfishes (winter flounder, Chapman et

404 al. 2004; turbot, Zheng et al. 2010), their expression pattern and function are largely

405 unknown. Our results suggest that this enzyme plays a role as the settlement stage begins.

406 Furthermore, the higher prx6 gene expression at settlement could indicate that cellular

407 maintenance under normal physiological conditions in blood, heart, muscle, and kidney is

408 completely functional from settlement in winter flounder. Indeed, while prx6 was

409 detected in most organs of the turbot (Zheng et al. 2010, using quantitative PCR) and of

410 the catfish (Yeh and Klesius 2007, using semi-quantitative PCR), its highest expression

411 levels were detected in these organs and the lowest in spleen. The detoxification of

412 hydrogen peroxide at settlement by Prx6 could be reinforced by the G6pd activity since

413 prx6 and g6pd both showed an increase in gene expression at settlement. G6pd activity

414 would provide a reductive potential in the form of nicotinamide adenine dinucleotide

415 phosphate-oxidase (NADPH), which is able to detoxify hydrogen peroxide (Pandolfi et

416 al. 1995). These results indicate that, in addition to high energy synthesis, the shift from 
417 glycolysis to the pentose-phosphate pathway at settlement provides an additional

418 antioxidant protection during settlement.

419 Starting from S15, the marked increase in $h s p 70$ gene expression suggested high

420 environmental stress due to marked metabolic and cellular changes caused by ontogenetic

421 metamorphosis processes occurring during settlement in winter flounder (Tanaka et al.

422 1996; Gibson 1997). The development of cytoprotection and possible oxidative defence

423 through $h s p 70$ toward the end of fish metamorphosis has also been reported by Deane

424 and Woo (2003) in silver sea bream Sparus sarba. These authors found unaltered $h s p 70$

425 transcript levels from 1-14 days post hatching that further progressively increased until

426 settlment. However, data are not available regarding the $h s p 70$ gene expression after the

427 settlement process.

428 The different expression patterns measured in our study for $\operatorname{sod}, h s p 70$, and $p r x 6$,

429 mostly observed at settlement or 15 days later $(h s p 70$, sod), could partly be linked with

430 changes in feeding behaviour and digestive physiology observed during this period in

431 natural environments (Tanaka et al. 1996; Lagardère et al. 1999; Cañavate et al. 2006).

432 Previous studies demonstrated that dietary components can affect levels of antioxidant

433 enzymes in the larval and adult life stages of organisms (Peters and Livingstone 1996).

434 This hypothesis would be supported by the changes in energy metabolism that we

435 observed throughout the fish development in this study.

437 To conclude, our results revealed several important points. (1) Two critical stages

438 could be identified during winter flounder metamorphosis: a) the transition from the

439 pelagic to the benthic habitat and b) the metamorphosis maturation, when the larvae stay 
440 settled without growth. They allow a more precise identification of the start of the

441 juvenile stage as the period denoted by the resumption of growth and the increased

442 aerobic capacity that occur approximately 30 days after settlement under the temperature

443 and photoperiod conditions used in the present experiment. (2) gh gene expression could

444 be a useful indicator of these main phases of development because its first expression

445 increase corresponds to the settlement phase while the second and more intense increase

446 corresponds to the beginning of the juvenile stage. (3) The results suggest that pelagic

447 larvae have a higher anaerobic capacity, while juveniles have a higher aerobic capacity

448 associated with a significant increase in growth rate. (4) The results suggest different

449 sources of energy synthesis for the different developmental stages: a) through glycolysis

450 in PL, b) through the pentose-phosphate pathway in settled larvae, and c) through lipid

451 metabolism in juveniles. (5) During the pelagic larval stage, oxidative stress and the

452 consequent antioxidative protection may be limited by glycolysis, while an increase in

453 antioxidative protection reinforced by the shift to the pentose-phosphate pathway seemed

454 to occur at settlement. Gene expression related to antioxidative protection was very high

455 in juveniles, certainly due to the higher growth rate observed at this period. (6) The

456 results suggest that cellular maintenance in organs such as blood, heart, muscle, and

457 kidney is fully functional from settlement, whereas the pancreas may continue to develop

458 until 30 days after settlement. The whole set of results obtained provides useful

459 preliminary indicators for the metamorphosis progress in this species and in larval fishes

460 through the understanding of molecular events governing ontogeny. However, because

461 post-transcriptional regulations may occur, it would be interesting to complete these

462 results with enzymatic measurements. Moreover, a future study should also include the 
463 evaluation of gene expression for a greater number of genes in the different pathways of

464 interest. Finally, other novel factors, including both known and unknown genes and

465 pathways, could be identified by new transcriptomic tools such as the use of RNAseq.

466

467 Acknowledgments

468

469 This work was supported by the FQRNT (Fonds Québecois pour la Recherche, Nature et

470 Technologies) to C. Audet, R.Tremblay, and J.-M. Sévigny, and by a FONCER

471 (CRSNG) grant for M. Vagner and B. de Montgolfier (post-doctoral fellowship from

472 Réseau Aquaculture Québec). The authors are very grateful to R. Gagné and E. Fraboulet

473 for sampling and fish rearing; to A. Lemieux and M.-A. Lafille for their help with qPCR

474 analyses; and to E. Parent for his help with sequencing.

475

476 References

477 Aceto, A., Amicarelli, F., Sacchetta, P., Dragani, B., Bucciarelli, T., Masciocco, L.,

478 Miranda, M., and Di Ilio, C. 1994. Developmental aspects of detoxifying enzymes in fish

479 (Salmo iridaeus). Free Radical Res. 21 (5): 285-294. DOI: 10.3109/10715769409056581

480 Altschul, S.F., Gish, W., Miller, W., Myers, E.W., and Lipman, D.J. 1990. Basic local

481 alignment search tool. J. Mol. Biol. 215 (3): 403-410. DOI 10.1016/S0022-

$482 \quad 2836(05) 80360-2$

483 Baolong, B., Yang, G., Liu, Z., Li, S., Wang, Z., and Ren, D. 2005. Isolation of SFRS3

484 gene and its differential expression during metamorphosis involving eye migration of 
485 Japanese flounder Paralichthys olivaceus. Biochim. Biophys. Acta, 1725: 64-70. DOI:

$486 \quad 10.1016 /$ j.bbagen.2005.04.032

487 Ben Khemis, I., de la Noue, J., and Audet, C. 2000. Feeding larvae of winter flounder

488 Pseudopleuronectes americanus (Walbaum) with live prey or microencapsulated diet:

489 linear growth and protein, RNA and DNA content. Aquacult. Res. 31 (4): 377-386. DOI:

$490 \quad 10.1046 / j .1365-2109.2000 .00456 . x$

491 Benoît, H.P., Pepin, P., and Brown, J.A. 2000. Patterns of metamorphic age and length in

492 marine fishes, from individuals to taxa. Can. J. Fish. Aquat. Sci. 57 (4): 856-869. DOI:

$493 \quad 10.1139 /$ f00-019

494 Benson, D.A., Karsch-Mizrachi, I., Lipman, D.J., Ostell, J., and Wheeler, D.L. 2005.

495 GenBank. Nucleic Acids Res. 33: D34-D38. DOI: 10.1093/nar/gkj157

496 Bishop, R.E., and Torres, J.J. 1999. Leptocephalus energetics: metabolism and excretion.

497 J. Exp. Biol. 202 (18): 2485-2493. DOI: 10.1007/s002270100541

498 Bishop, C.D., Erezyilmaz, D.F., Flatt, T., Georgiou, D.C., Hadfield, M.G., Heyland, A.,

499 Hodin, J., Jacobs, M.W., Maslakova, S.A., Pires, A., Reitzel, A.M., Santagata, S.,

500 Tanaka, K., and Youson, J.H. 2006. What is metamorphosis? Integr. Comp. Biol. 46 (6):

501 655-661. DOI: 10.1046/j.1525-142X.2003.03059.x

502 Borlongan, I.G. 1990. Studies on the digestive lipases of milkfish, Chanos chanos.

503 Aquaculture, 89: 315-325. DOI: 10.1016/0044-8486(90)90135-A

504 Cañavate, P. J., Zerolo, R., and Fernandez-Diaz, C. 2006. Feeding and development of

505 Senegal sole (Solea senegalensis) larvae reared in different photoperiods. Aquaculture,

506 258: 368-377. DOI: 10.1016/j.aquaculture.2006.04.009

507 Chambers, R.C., and Leggett, W.C. 1987. Size and age at metamorphosis in marine 
508 fishes: an analysis of laboratory-reared winter flounder (Pseudopleuronectes americanus)

509 with a review of variation in other species. Can. J. Fish. Aquat. Sci. 44: 1936-1947. DOI:

$510 \quad 10.1139 / 887-238$

511 Chambers, R.C., and Leggett, W.C. 1992. Possible causes and consequences of variation

512 in age and size at metamorphosis in flatfishes (Pleuronectiformes): an analysis at the

513 individual, population, and species levels. Neth. J. Sea Res. 29 (1-3): 7-24. DOI:

$514 \quad 10.1016 / 0077-7579(92) 90004-x$

515 Chapman, L.M., Roling, J.A., Bingham, L.K., Herald, M.R., and Baldwin, W.S. 2004.

516 Construction of a subtractive library from hexavalent chromium treated winter flounder

517 (Pseudopleuronectes americanus) reveals alterations in non-selenium glutathione

518 peroxidases. Aquat. Toxicol. 67 (2): 181-194. DOI: 10.1016/j.aquatox.2003.12.006

519 Childress, J.J., and Somero, G.N. 1990. Metabolic scaling: a new perspective based on

520 scaling of glycolytic enzyme activities. Integr. Comp. Biol. 30 (1): 161-173. DOI:

$521 \quad 10.1093 / \mathrm{icb} / 30.1 .161$

522 Darias, M.J., Zambonino-Infante, J.L., Hugot, K., Cahu, C. L., and Mazurais, D.

523 2008. Gene expression patterns during the larval development of European sea bass

524 (Dicentrarchus labrax) by microarray analysis. Mar. Biotechnol. 10 (4): 416-428. DOI:

$525 \quad 10.1007 / \mathrm{s} 10126-007-9078-1$

526 Deane, E., and Woo, N.Y.S. 2003. Ontogeny of thyroid hormones, cortisol, hsp70 and

527 hsp90 during silver sea bream larval development. Life Sci. 72 (7): 805-818. DOI:

$528 \quad 10.1016 / \mathrm{S} 0024-3205(02) 02334-2$ 
529 Díaz, M.E., Furné, M., Trenzado, C.E., García-Gallego, M., Domezain, A., and Sanz, A.

530 2010. Antioxidant defences in the first life phases of the sturgeon Acipenser naccarii.

531 Aquaculture, 307 (1-2): 123-129. DOI: 10.1016/j.aquaculture.2010.06.026

532 Escobar, S., Fuentes, E.N., Poblete, E., Valdés, J.A., Safian, D., Reyes, A.E., Álvarez, 533 M., and M., Molina, A. 2011. Molecular cloning of IGF-1 and IGF-1 receptor and their 534 expression pattern in the Chilean flounder (Paralichthys adspersus). Comp. Biochem.

535 Physiol. B 159 (3): 140-147. DOI: 10.1016/j.cbpb.2011.03.003

536 Fraboulet, E., Lambert, Y., Litvak, M., and Audet, C. 2009. The effects of latitudinal

537 origin and paternal contribution on larval growth of winter flounder in a northern

538 environment. Trans. Am. Fish. Soc. 138: 407-415. DOI: 10.1577/T08-014.1

539 Fraboulet, E., Lambert, Y., Tremblay, R., and Audet, C. 2010. Assessment of paternal

540 effect and physiological cost of metamorphosis on growth of young winter flounder

541 Pseudopleuronectes americanus juveniles in a cold environment. J. Fish Biol. 76 (4):

542 930-948. DOI: $10.1111 /$ j.1095-8649.2010.02538.x

543 Fraboulet, E., Lambert, Y., Tremblay, R., and Audet, C. 2011. Growth and lipid

544 composition of winter flounder juveniles reared under variable photoperiod and

545 temperature conditions. N. Am. J. Aquacult. 73: 89-96.

546 Fridovich, I. 2004. Mitochondria: are they the seat of senescence? Aging Cell, 3 (1): 13-

547 16. DOI: $10.1046 / j .1474-9728.2003 .00075 . x$

548 Fuiman, L. 1997. What can flatfish ontogenies tell us about pelagic and benthic

549 lifestyles? J. Sea Res. 37 (3-4): 257-267. DOI: 10.1016/S1385-1101(97)00013-0

550 Geffen, A.J., van der Veer, H.W., and Nash, R.D.M. 2007. The cost of metamorphosis in

551 flatfishes. J. Sea Res. 58 (1): 35-45. DOI: 10.1016/j.seares.2007.02.004 
552 Gibson, R. 1997. Behaviour and the distribution of flatfishes. J. Sea Res. 37 (3-4): 241-

553 256. DOI: 10.1016/S1385-1101(97)00019-1

554 Heyland, A., and Moroz, L.L. 2006. Signaling mechanisms underlying metamorphic

555 transitions in animals. Integr. Comp. Biol. 46: 743-759. DOI: 10.1093/icb/ic1023

556 Hildahl, J., Sweeney, G., Galay-Burgos, M., Einarsdóttir, I.E., and Björnsson, B.T.

557 2007. Cloning of Atlantic halibut growth hormone receptor genes and quantitative gene

558 expression during metamorphosis. Gen. Comp. Endocrinol. 151: 143-152. DOI:

559 10.1016/j.ygcen.2006.10.003

560 Hildahl, J., Power, D.M., Björnsson, B.T., and Einarsdóttir, E.I. 2008. Involvement of

561 growth hormone-insulin-like growth factor I system in cranial remodeling during halibut

562 metamorphosis as indicated by tissue- and stage-specific receptor gene expression and

563 the presence of growth hormone receptor protein. Cell Tissue Res. 332 (2): 211-225.

564 DOI: $10.1007 / \mathrm{s} 00441-007-0568-2$

565 Hoehne-Reitan, K. 2001. Development of bile salt-dependent lipase in larval turbot. J.

566 Fish Biol. 58 (3): 737-745. DOI: 10.1111/j.1095-8649.2001.tb00526.x

567 Infante, C., Asensio, E., Cañavate, J.P., and Manchado, M. 2008. Molecular

568 characterization and expression analysis of five different elongation factor 1 alpha genes

569 in the flatfish Senegalese sole (Solea senegalensis Kaup): Differential gene expression

570 and thyroid hormones dependence during metamorphosis. BMC Molecular Biology, (9):

571 1-19. DOI: $10.1186 / 1471-2199-9-19$

572 Kalaimani, N., Chakravarthy, N., Shanmugham, R., Thirunavukkarasu, A.R., Alavandi,

573 and S.V., Santiago, T.C. 2007. Anti-oxidant status in embryonic, post-hatch and larval 
574 stages of Asian seabass (Lates calcarifer). Fish Physiol. Biochem. 34 (2): 151-158. DOI:

$575 \quad 10.1007 / \mathrm{s} 10695-007-9155-4$

576 Lagardère, F., Amara, R., and Joassard, L. 1999. Vertical distribution and feeding activity

577 of metamorphosing sole, Solea solea, before immigration to the Bay of Vilaine nursery

578 (northern Bay of Biscay, France). Environ. Biol. Fishes, 56 (1): 213-228. DOI:

$57910.1023 / \mathrm{A}: 1007581818941$

580 Livak, K.J., and Schmittgen, T.D. 2001. Analysis of relative gene expression data using

581 real-time quantitative PCR and the $2-\Delta \Delta \mathrm{CT}$ method. Methods, 25: 402-408. DOI:

$582 \quad 10.1006 /$ meth.2001.1262

583 Mourente, G., Tocher, D.R., Diaz, E., Grau, A., and Pastor, E. 1999. Relationships

584 between antioxidants, antioxidant enzyme activities and lipid peroxidation products

585 during early development in Dentex dentex eggs and larvae. Aquaculture, 179 (1-4): 309-

586 324. DOI: 10.1016/S0044-8486(99)00167-2

587 Munilla-Moran, R., and Stark, J. 1989. Biochemical studies in marine species-I. NADP+-

588 dependent isocitrate dehydrogenase from turbot liver (Scophthalmus maximus L.). Comp.

589 Biochem. Physiol. B 93 (4): 823-828.

590 Murray, H.M., Gallant, J.W., Perez-Casanova, J.C., Johnson, S.C., and Douglas, S.E.

591 2003. Ontogeny of lipase expression in winter flounder. J. Fish Biol. 62 (4): 816-833.

592 DOI: 10.1046/j.1095-8649.2003.00067.x

593 Pandolfi, P.P., Sonati, F., Rivi, R., Mason, P., Grosveld, F., and Luzzatto, L. 1995.

594 Targeted disruption of the housekeeping gene encoding glucose 6-phosphate

595 dehydrogenase (G6PD): G6PD is dispensable for pentose synthesis but essential for

596 defense against oxidative stress. EMBO J. 14 (21): 5209-5215 
597 Pérez-Sánchez, J., Bermejo-Nogales, A., Calduch-Giner, J.A., Kaushik, S., and Sitjà-

598 Bobadilla, A. 2011. Molecular characterization and expression analysis of six

599 peroxiredoxin paralogous genes in gilthead sea bream (Sparus aurata): Insights from fish

600 exposed to dietary, pathogen and confinement stressors. Fish Shellfish Immunol. 31 (2):

601 294-302. DOI: 10.1016/j.fsi.2011.05.015

602 Peters, L., Porte, C., and Livingstone, D. 2001. Variation of antioxidant enzyme activities

603 of sprat larvae and organic contaminant levels in mixed zooplankton from the Southern

604 North Sea. Mar. Pollut. Bull. 42 (11): 1087-1095. DOI: 10.1016/S0025-326X(01)00088$605 \quad 1$

606 Peters, L.D., and Livingstone, D.R. 1996. Antioxidant enzyme activities in embryologic 607 and early larval stages of turbot. J. Fish Biol. 49 (5): 986-997. DOI:

$608 \quad 10.1006 /$ jfbi.1996.0227

609 Quinn, G., and Keough, M.J. 2002. Experimental design and data analysis for biologists.

610 New York: Cambridge University Press, Cambridge UK.

611 Ribeiro, L., Zambonino-Infante, J.L., Cahu ,C., and Dinis, M.T. 1999. Development of

612 digestive enzymes in larvae of Solea senegalensis, Kaup 1858. Aquaculture, 179 (1-4):

613 465-473. DOI: 10.1016/S0044-8486(99)00180-5

614 Rozen, S., and Skaletsky, H.J. 2000. Primer3 on the WWW for general users and for

615 biologist programmers. In Bioinformatics methods and protocols: methods in molecular

616 biology. Edited by S. Krawetz and S. MisenerHumana Press, Totowa, NJ,. p. 365-386

617 Scott, W.B., and Scott, M.G., 1988. Atlantic fishes of Canada. Can. Bull. Fish. Aquat.

618 Sci. 219.

619 Segner, H., and Verreth, J. 1995. Metabolic enzyme activities in larvae of the African 
620 catfish, Clarias gariepinus: changes in relation to age and nutrition. Fish Physiol.

621 Biochem. 14 (5): 385-398. DOI: 10.1007/BF00003376

622 Seychelles, L.H., Audet, C., Tremblay, R., Fournier, R., and Pernet, F. 2009. Essential

623 fatty acid enrichment of cultured rotifers (Brachionus plicatilis, Müller) using frozen-

624 concentrated microalgae. Aquacult. Nutr. 15 (4): 431-439. DOI: 10.1111/j.1365-

$625 \quad 2095.2008 .00608 . x$

626 Slenzka, K., Appel, R., and Rahmann, H. 1995. Development and altered gravity

627 dependent changes in glucose-6-phosphate dehydrogenase activity in the brain of the

628 cichlid fish Oreochromis Mossambicus. Neurochem. Int. 26 (6): 579-585. DOI:

$629 \quad 10.1016 / 0197-0186(94) 00176-U$

630 Tanaka, M., Kawai, S., Seikai, T., and Burke, J.S. 1996. Development of the digestive

631 organ system in Japanese flounder in relation to metamorphosis and settlement. Mar.

632 Freshw. Behav. Physiol. 28 (1): 19-31. DOI: 10.1080/10236249609378976

633 Wang, X., Tan, Y., Sievers, Q., Sievers, B., Lee, M., Burrall, K., and Schreiber, A. M.

634 2011. Thyroid hormone-responsive genes mediate otolith growth and development during

635 flatfish metamorphosis. Comp. Biochem. Physiol. A 158: 163-168. DOI:

$636 \quad 10.1016 /$ j.cbpa.2010.10.014

637 Wood, Z.A., Schröder, E., Harris, J.R., and Poole, L.B. 2003. Structure, mechanism and

638 regulation of peroxiredoxins. Trends Biochem. Sci. 28 (1): 32-40. DOI: 10.1016/S0968-

$639 \quad 0004(02) 00003-8$

640 Wu, S.B., and Wei, Y.H. 2011. AMPK-mediated increase of glycolysis as an adaptive

641 response to oxidative stress in human cells: Implication of the cell survival in

642 mitochondrial diseases. Biochim. Biophys. Acta, Mol. Basis Dis. 1822 (2): 233-247. 
643 DOI: 10.1016/j.bbadis.2011.09.014

644 Yeh, H.Y., and Klesius, P.H. 2007. cDNA cloning, characterization, and expression

645 analysis of channel catfish (Ictalurus punctatus Rafinesque, 1818) peroxiredoxin 6 gene.

646 Fish Physiol. Biochem. 33 (3): 233-239. DOI: 10.1007/s10695-007-9135-8

647 Yousefian, M., and Shirzad, E. 2011. The review of the effect of growth hormone on

648 immune system, metabolism and osmoregulation of fish. Aust. J. Basic Appl. Sci. 5(5):

$649 \quad 467-475$.

650 Zheng, W., Hu, Y., Zhang, M., and Sun, L. 2010. Analysis of the expression and

651 antioxidative property of a peroxiredoxin 6 from Scophthalmus maximus. Fish Shellfish

652 Immunol. 29 (2): 305-311. DOI: 10.1016/j.fsi.2010.04.008 
$1 \quad$ Figure 1
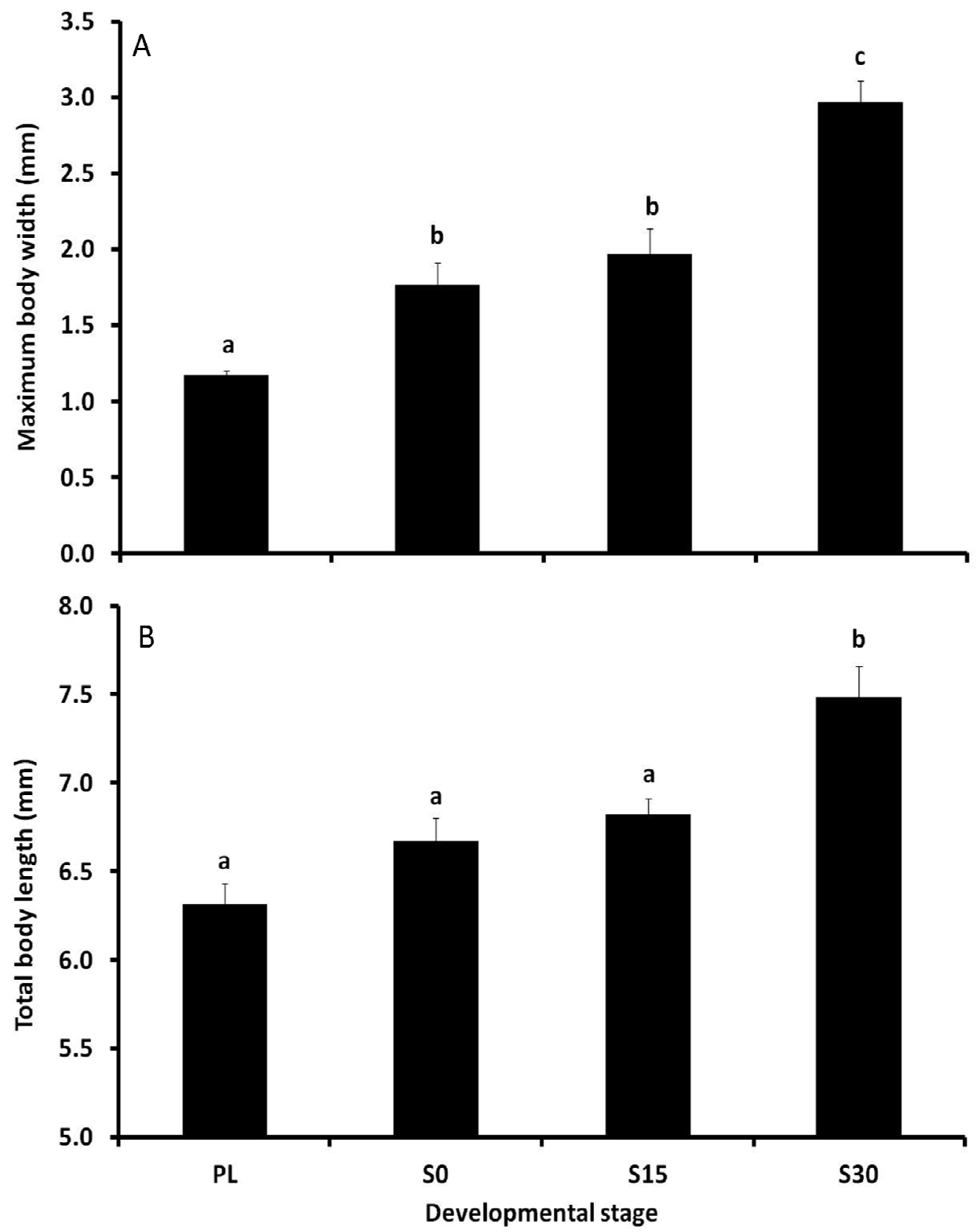

2

3

4 
$5 \quad$ Figure 2

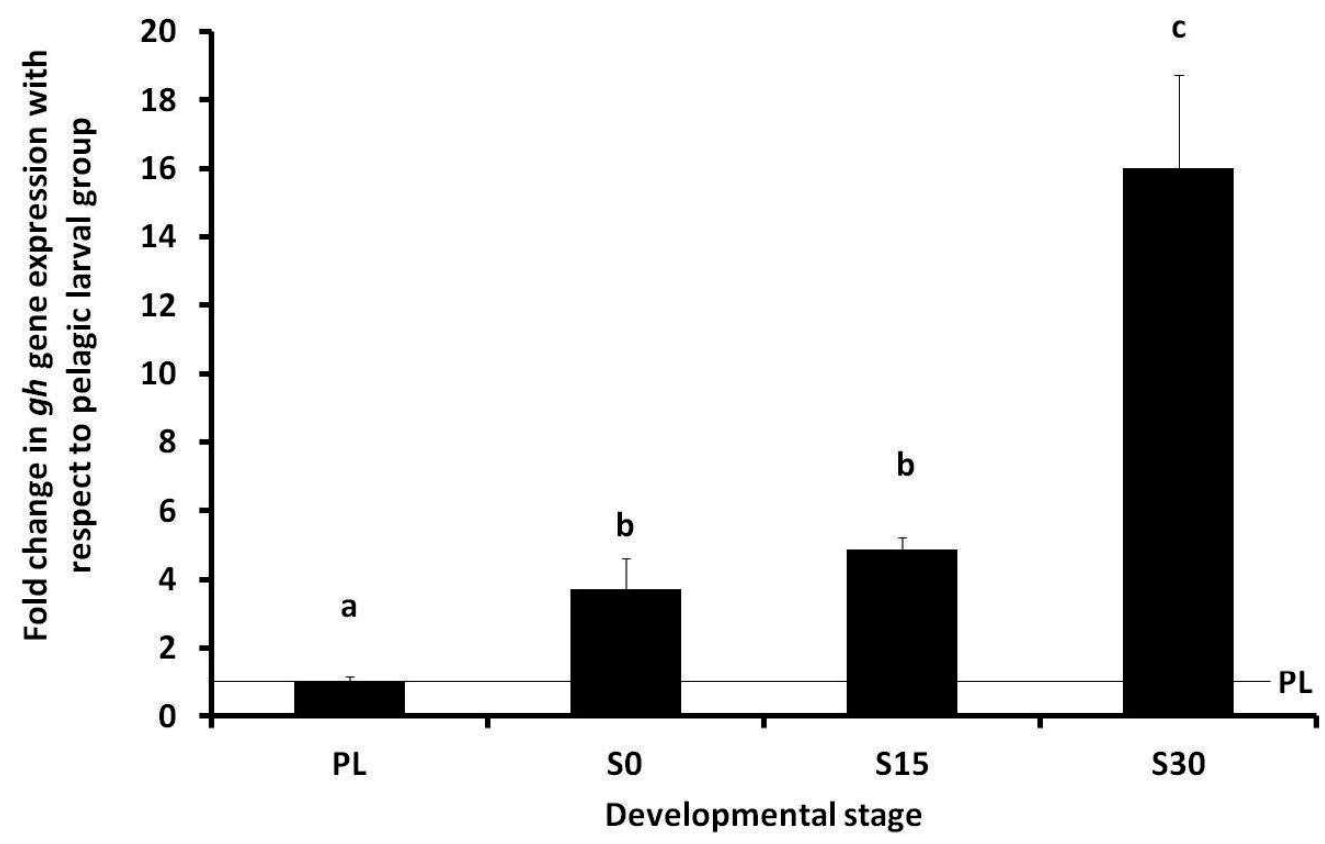


Figure 3
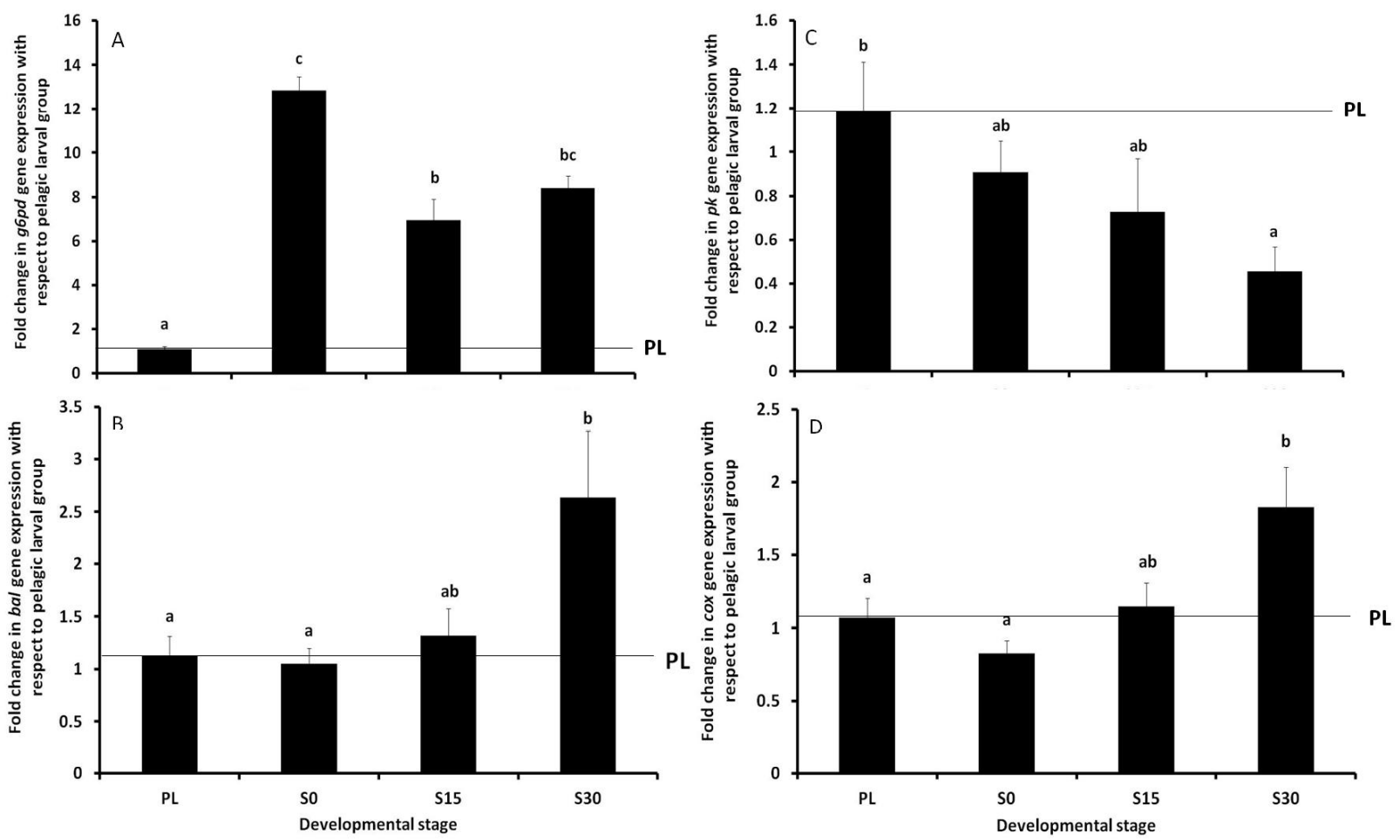
Figure 4
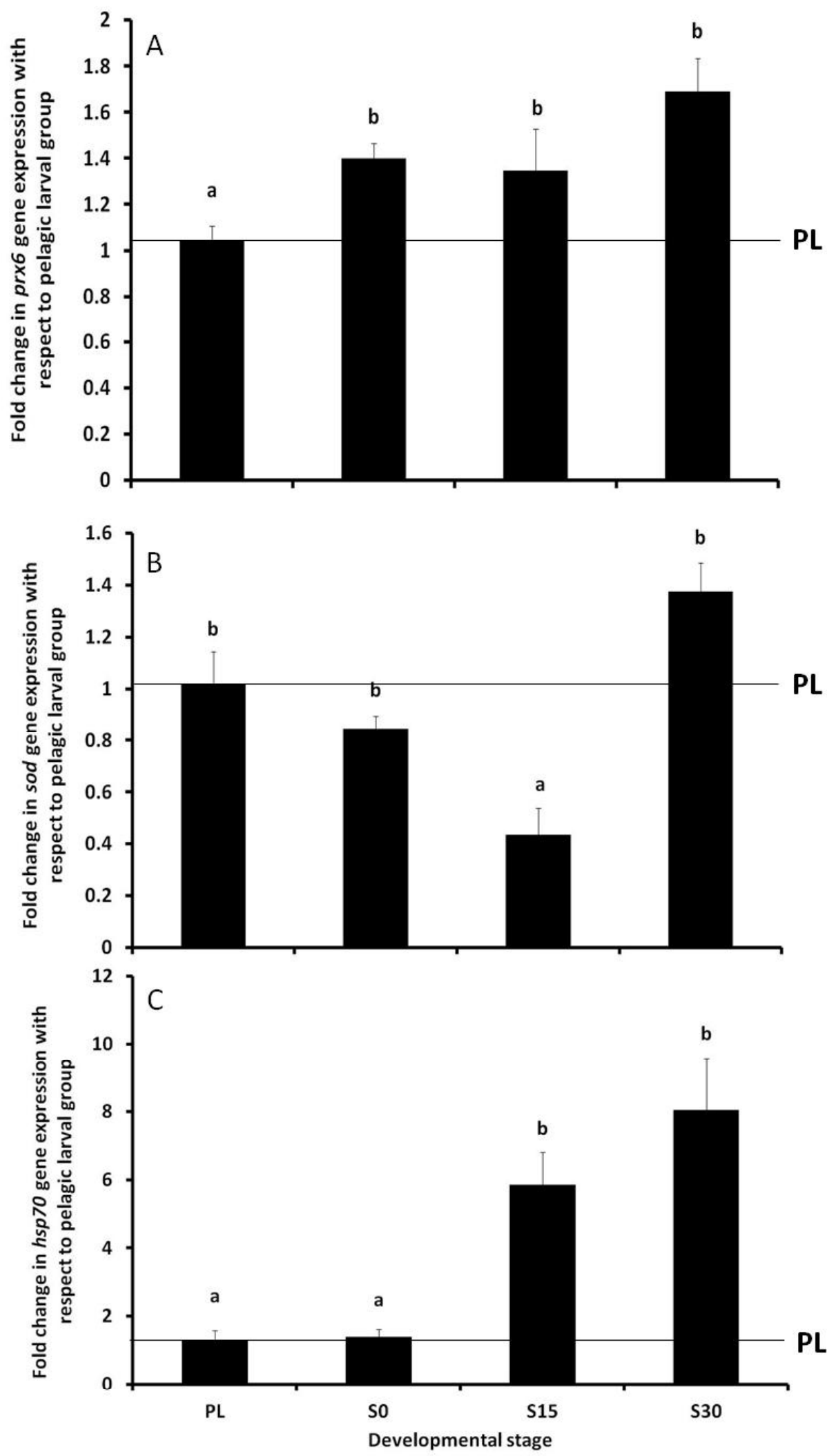